\title{
Off label, compassionate and irrational use of medicines in Covid-19 pandemic, health consequences and ethical issues
}

\author{
Uso off label, compassivo e irracional de medicamentos na pandemia \\ de Covid-19, consequências para a saúde e questões éticas
}

Francisco José Roma Paumgartten (https://orcid.org/0000-0002-6207-0149) ${ }^{1}$

Ana Cecilia Amado Xavier de Oliveira (https://orcid.org/0000-0002-5798-2258) ${ }^{1}$

${ }^{1}$ Escola Nacional de Saúde Pública, Fiocruz. Av. Brasil 4036/913, Manguinhos. 21040-361. Rio de Janeiro, RJ, Brasil. paum@ensp.fiocruz.br

\begin{abstract}
When Covid-19 emerged in December last year, there was no vaccine nor was there specific effective treatment for this fast-spreading and life-threatening viral respiratory infection. Clinical trials were planned and are in progress to investigate whether drugs used for influenza, HIV and other viruses, and also anthelmintics (ivermectin, nitazoxanide, niclosamide), and antimalarials (chloroquine, hydroxychloroquine) showing antiviral activity in in vitro assays, are effective and safe for Covid-19. So far there is no convincing evidence that these antiviral and antiparasitic drugs are of any benefit for Covid-19. Notwithsanding the absence of evidence of clinical efficacy, these drugs are widely used outside of clinical trials (off label) for prophylaxis and treatment of this viral infection. The rationale behind the prescription of macrolide antibiotics (azithromycin) for Covid-19 is obscure as well. The widespread prescription and use of drugs of unproven efficacy and safety for Covid-19 is at odds with the rational use of medicines, a cornerstone principle of pharmacotherapy advanced by WHO in 1985. This irrational use of drugs is cause for concern because some of them are associated with serious heart disorders and deaths.
\end{abstract}

Key words SARS-CoV-2, Drug adverse events, Pharmacotherapy, Hydroxychloroquine, Antibiotics
Resumo Quando a Covid-19 surgiu em dezembro do ano passado, não havia vacina nem tratamento eficaz específico para esta infeç̧ão respiratória viral de rápida disseminação e risco de vida. Ensaios clínicos foram planejados e estão em andamento para investigar se os medicamentos usados para influenza, HIV e outros virus e também anti-helmínticos (ivermectina, nitazoxanida, niclosamida) e antimaláricos (cloroquina, hidroxicloroquina) mostrando atividade antiviral em ensaios in vitro são eficazes e seguros para Covid-19. Até o momento, não há evidências convincentes de que esses medicamentos antivirais $e$ antiparasitários sejam benéficos para a Covid-19. Não obstante a ausência de evidência de eficácia clínica, esses medicamentos são amplamente utilizados fora dos ensaios clínicos (off label) para profilaxia e tratamento dessa infecção viral. A lógica por trás da prescrição de antibióticos macrolídeos (azitromicina) para a Covid-19 também é obscura. A ampla prescrição e uso de medicamentos de eficácia e segurança não comprovadas para a Covid-19 está em desacordo com o uso racional de medicamentos, um princípio fundamental da farmacoterapia promovido pela OMS em 1985. Esse uso irracional de medicamentos é motivo de preocupação, porque alguns deles estão associados a graves doenças cardíacas e mortes.

Palavras-chave SARS-CoV-2, Eventos adversos a medicamentos, Farmacoterapia, Hidroxicloroquina, Antibióticos 


\section{Introduction}

There is nothing like a frightening pandemic for spreading unfounded beliefs in 'miraculous' medications. The Covid-19 pandemic is not an exception. Tackling such a life-threatening infection for which there is no vaccine nor are there specific effective therapies, not only lay people, but also physicians and public health practioners may feel tempted to adopt healthcare practices that are not based on the best available scientific information. It is not suprising, therefore, a widespread prescription and use of medicines that were not approved, nor were demonstrated to be effective for Covid-19. This off label use of drugs for primary treatment of Covid-19 is not compliant with WHO's notion of rational use of medicines (RUM) ${ }^{1}$.

The concept of rational use of medicines (RUM), advanced by WHO in 1985, states that the use of medicines is rational when patients receive medications appropriate to their clinical needs, in doses that meet their own individual requirements, for an adequate period of time, and at the lowest cost to them and their community ${ }^{1}$. That is, the use of medicines is deemed irrational or non-rational, whenever it is not compliant with any of the foregoing requirements. From a slightly distinct perspective, the World Bank endorsed the WHO's notion of RUM stressing that it integrates two key principles: use of drugs according to scientific data on efficacy, safety and compliance, and cost-effective use of drugs within the constraints of a given health system ${ }^{2}$. Examples of irrational prescription and use of drugs are the use of too many medicines per patient (polypharmacy), the inappropriate use of antibiotics for non-bacterial infections, the failure to prescribe in accordance with the best evidence-based clinical guidelines, and inappropriate self-medication ${ }^{1}$.

RUM is consistent with a healthcare practice known as Evidence-Based Medicine (EBM) ${ }^{3}$. As explained by David Sackett, one of the physicians who pioneered the concept in the 1990s, EBM is the conscientious, explicit, and judicious use of current best evidence in making decisions about the care of individual patients ${ }^{3}$. Obviously, drugs appropriate to patient clinical needs are those of proven efficacy and safety to treat his/ her medical condition, prescribed and used according to the best available empiric evidence on the effective and safe dose regimens, and that are the most cost-effective pharmacotherapy. Therefore, as far as therapeutic approaches are concerned, EBM-guided practices imply in selecting the most suitable pharmacological intervention based on the best available scientific evidence.

Five months or so of the emergence of the pandemic, in many cases, the primary pharmacotherapy of Covid-19 seems to be based on physicians` guesses on what drug, or combination of drugs should work, rather than on the best empiric evidence from clinical trials. This conduct of practicioners are understandable, but not justifiable.

When mankind was struck by the pandemic, there was no antiviral drug of proven efficacy against SARS-CoV-2, nor were there evidence-based guidance and protocols of how to treat Covid-19 patients. There were on the market, however, a few drugs for other viral diseases such as inhibitors of viral neuraiminidase (oseltamivir / zanamivir), RNA polymerase (favipiravir), and cell membrane fusion (umifenovir) for influenza $\mathrm{A}$ and $\mathrm{B}$, protease inhibitors (lopinavir/ritonavir, darunavir) for HIV, and a guanosine (ribonucleic) analog inhibitor of virus RNA synthesis (ribavirin) for hepatitis $C$, respiratory syncytial virus (RSV) and other infections ${ }^{4}$. Moreover, it was known that the antimalarial compounds chloroquine and hydroxychloroquine, and anthelmintics such as ivermectin, nitazoxanide and niclosamide strongly inhibited the replication of a variety of RNA (including SARS-CoV) and DNA viruses in cell-culture-based screening assays ${ }^{4}$. These medicines began to be widely prescribed (off label) while clinical trials were still in progress to investigate whether they were in fact effective (and safe) for Covid-19 and thus could be repurposed for the treatment of this viral infection.

A major problem with off label prescription and use of medicines is that whereas their health risks (based on the use for approved indications) are generally predictable, their effectiveness for a new indication (Covid-19) is still undemonstrated and cannot be taken for granted.

In the case of medicines approved for other viral infections, the antiviral mode of action may not work for SARS-CoV-2. For instance, since SARS-CoV-2 and other coronaviruses are enveloped positive sense single-stranded RNA viruses $^{4,5}$, they do not synthesize a complementary DNA and, thus, inhibitors of reverse transcriptidase (like AZT or azidothymidine, active against HIV) do not block their replication ${ }^{4,5}$. Moreover, differences among viruses regarding the sctrucure of the viral protein targeted by the drug, the mode by which viruses replicate (cell entry, multiplication and release), and the progression of infection in humans may eventually 
result in distinct clinical responses of viruses to antiviral agents. In summary, drugs that proved to work against influenza, hepatitis C or HIV, are not necessarily effective for Covid-19 and effectiveness against SARS-CoV-2 has to be confirmed by specific clinical trials.

When SARS-CoV-1 outbreak emerged in 2002-2003, oseltamivir and ribavirin were used (off label) and the clinical response of a small group of patients was followed up. A study of this case-series did not bring to light any clear therapeutic benefit of the two drugs ${ }^{6}$. It is of note that, owing to the small number of infected people and relatively short duration of the outbreak, it was not feasible to plan and conduct RCTs on drug therapies for SARS-CoV-1 ${ }^{7,8}$. Therefore, information on possibly effective (or proven ineffective) antivirals for a closely related infection (SARS-CoV-1) was not available for trackling the SARS-CoV-2 (Covid-19) pandemic.

In the early 2000s, it was proposed that the antimalarials chloroquine (CQ), hydroxychloroquine (HCQ) and artemisinin"-11 the anthelmintics ivermectin, nitazoxanide and niclosamide, and indomethacin (anti-inflammatory) could be useful compounds to treat a diversity of viral infections including the then emerging virus SARS$\mathrm{CoV}-1^{12-16}$. This hypothesis was based on results from cell culture-based assays showing that all these antiparasitic drugs exhibited potent antiviral activity against a variety of viruses. In the case of the antimalarial 4-aminoquinolines (CQ and HCQ) and indomethacin it was also speculated that their anti-inflammatory and/or immunosuppressive action would add to the inhibition of viral replication in the clinical management of the lung hyperinflammation and Acute Respiratory Distress Syndrome caused by SARS-CoV-1 (and also SARS-CoV-2) infection ${ }^{10,11}$.

There is a profound divide, however, between a strong antiviral activity noted in in vitro test systems and effectiveness and safety to treat Covid-19 patients. In vitro antiviral activity is not always translated into in vivo therapeutic responses, and antiviral activity in animals does not necessarily imply in clinical effectiveness. Sufficiently large randomized placebo-controlled (RCT) clinical trials, with masking and concealment of allocation, are needed to bridge this divide.

\section{Off label prescription for Covid-19, risk to benefit balance and ethical issues}

Off label drug prescription is not forbidden, nor does it necessarily imply in irrational phar- macotherapy. Physicians, however, must be aware that, when prescribing an unapproved drug, they take full responsibility for any harmful consequence for their patients, even if patients had signed an Informed Consent form. It is assumed that doctors, but not their patients, are fully capable of weighing risks of adverse events against potential benefits of prescribed therapy.

If drug efficacy for Covid-19 remains unproven, and so uncertain, even small risks of adverse effects must be taken seriously into account. Moreover, when drugs are prescribed off label for prophylaxis and/or asymptomatic or mild Covid-19, doctors should have in mind that, for most treated patients, even if the drug were in fact effective, clinical benefits would be minimum or non-existent. It is estimated that most (80\%) Covid-19 patients experience mild to moderate symptoms with spontaneous resolution of the infection, while about one-fifth of them $(20 \%)$ develop severe respiratory symptoms and the Acute Respiratory Distress Syndrome $(A R D S)^{17}$. In $6.1 \%$ or so of all infected patients the disease symptoms worsen considerably to the extent that mechanical ventilation is needed ${ }^{17}$. It should also be borne in mind that risks of drug adverse events that might be considered tolerable for critically-ill patients might not be acceptable for those who present only mild symptoms and are likely to progress to spontaneous healing.

Based on the foregoing, drugs entailing risks of major adverse events and having narrow margins of safety (MOS) must not be prescribed and used off label for prophylaxis and treatment of mild Covid-19.

\section{Off label use of chloroquine (CQ) and hydroxychloroquine (HCQ)}

The widespread use of CQ and its hydroxylated derivative HCQ for Covid-19 is perhaps the best example of off label drug use that is irrational and is likely to cause more harm than benefits. The hypothesis that CQ/HCQ could be useful to treat SARS-CoV-1 and other viral infections was advanced by Savarino et al in $2003^{10}$. When SARS-CoV-2 outbreak emerged in Wuhan in December 2019 / January 2020, CQ/HCQ was one of several drugs potentially repurposable for Covid-19 that were selected for testing in clinical trials $^{18}$. In parallel to clinical research, CQ and HCQ often in association with the macrolide antibiotic azithromycin (AZM) started to be extensively used to treat Covid-19 outside clinical trials as well. The off label prescription of CQ and 
HCQ was apparently boosted by early reports of open, non-randomized and definitely underpowered studies suggesting that these 4 -aminoquinolines plus AZM could be of benefit for severely-ill Covid-19 patients $^{19}$, although other preliminary (pilot) studies also showed no apparent benefit ${ }^{20}$.

Both CQ and HCQ are narrow MOS medicines causing a number of severe adverse events including ophthalmologic sequelae (retinopathy and loss of vision) and life-threatening heart disorders, such as QT interval prolongation, arrhythmias and cardiac arrest ${ }^{4,11,21}$. Along this line, the US FDA has issued a warning (April $24^{\text {th }} 2020$ ) about serious adverse events, such as QT interval prolongation, ventricular tachycardia and ventricular fibrillation, and deaths, in patients with Covid-19 who had made use of CQ/ $\mathrm{HCQ}$, either alone or combined with $\mathrm{AZM}^{22}$. A recent analysis of WHO's pharmacovigilance database reported signals of potentially lethal cardiac proarrhythmogenic effects leading to ventricular arrhythmias with AZM, and also with HCQ, and that HCQ plus AZM combination yielded an even stronger signal ${ }^{23}$.

Recently-published results of an observational retrospective study of hospitalized Covid-19 patients (New York, US) treated (off label) with HCQ, AZM, or both, compared with neither treatment found no association of treatment with HCQ or AZM or both with higher or lower risk of intubation or death ${ }^{24}$. Notwithsanding suggesting that HCQ was not effective for Covid-19, this study suffers from limitations inherent to observational designs ${ }^{4,24}$. It is of note that, whereas clinical trials yielded no convincing evidence that CQ/HCQ (alone or with AZM) is of benefit for Covid-19, this possibility cannot be ruled out because most studies have a poor design and methodological limitations s,11,18,24 $^{\text {. Large }}$ RCT trials with masking and concealment of allocation, therefore, remain needed for reaching a definitive conclusion about effectiveness of CQ or HCQ for Covid-19. The available evidence, however, is sufficient to strongly recommend not to prescribe and use CQ or HCQ outside clinical trials (i.e., off label).

\section{Antibiotics in severe Covid-19, what is the rationale?}

The rationale behind the widespread prescription of macrolide antibiotics such as AZM, clarithromycin and carrimycin (mostly in China) for severe Covid-19 is obscure. Antibiotics are not active against viral respiratory infections and their use for non-bacterial infections is one of the most common examples of irrational use of medicines.

A recent analysis by the University of Oxford's Centre for Evidence-Based Medicine (Nuffield Department of Primary Care Health Sciences) has reached the conclusion (April $\left.28^{\text {th }}, 2020\right)$ that "there is insufficient evidence to recommend treatment with macrolides, alone or combined with hydroxychloroquine, for Covid-19 outside of research" ${ }^{25}$. This conclusion is in line with NICE (UK National Institute for Health and Care Excellence) guidelines that explicitly recommend: "not to offer an antibiotic for treatment or prevention of pneumonia if Covid-19 is likely to be the cause and symptoms are mild"26. Unless physicians are uncertain about the viral (SARSCoV-2) etiology of pneumonia, and/or cannot exclude the co-existence of viral and bacterial infections there is no apparent reason for prescribing antibiotics ${ }^{4,25,26}$. Moreover, prescribers should take into account that AZM has been associated with QT interval prolongation and that it should be avoided, or used very cautiously, in patients with severe renal or liver failure ${ }^{25}$.

\section{Compassionate use and emergency approval of remdesivir for Covid-19}

Compassionate use, also known as expanded access, is a possible way through which patients with an immediately life-threatening or serious medical condition have access to investigational drugs outside of clinical trials. Compassionate-use status requires approval by the regulatory agency, and it is generally obtained when no comparable or satisfactory alternative therapy options are available. In the pharmaceutical jargon, therefore, compassionate-use status differs from using drugs available on the market for unapproved indications, or off label use.

On May $1^{\text {st }} 2020$, the U.S. Food and Drug Administration issued an emergency use authorization for the investigational drug remdesivir (REM) for treatment of hospitalized patients with severe Covid-1997,28. This antiviral drug had been previously available only for patients enroled in clinical trials and for those cleared to get the drug under expanded use and compassionate use programs.

REM, a pro-drug, is an adenosine nucleoside triphosphate analog developed by US company Gilead Sciences. The REM active metabolite inhibits viral RNA-dependent RNA polymerase and, by doing so, it stops viral replication ${ }^{29}$. It was 
originally developed for hepatitis $\mathrm{C}$ but clinical trial results for hepatitis were frustrating. REM was then repurposed for Ebola virus infections and clinically tested during West Africa Ebola outbreak in 2013-2016. The initially promising results were not further confirmed and REM proved to less effective than monoclonal antibodies in the treatment of Ebola ${ }^{28,29}$.

Since in vitro assays indicated that REM strongly inhibited replication of SARS-CoV-1 and MERS-CoV viruses in several cell lines ${ }^{30,31}$, it was clinically tested for Covid-19. Data from a cohort of hospitalized patients with Covid-19, who had received REM on a compassionate-use basis, suggested that $36(68 \%)$ patients treated with this antiviral compound showed clinical improvement $^{32}$. A recent Chinese RCT (double-blinded and placebo-controlled) multicenter study found no evidence of overall clinical benefit of REM for Covid-19 patients with ARDS. The Chinese study, however, suggested that REM might have reduced time to clinical improvement among those patients treated earlier ${ }^{33}$. Afterwards, preliminary results (29 April 2020) of an ongoing US NIH-sponsored large (> 1000 participants) placebo-controlled RCT indicated that REM cut recovery time for hospitalized Covid-19 patients by four days, or $31 \%$ (i.e., about 11 days in RDV-treated against 15 days in the placebo group $)^{28,34}$. Death rate in REM-treated $(8 \%)$ and controls $(11 \%)$ did not differ statistically. Although suggesting a relatively modest therapeu- tic benefit, these preliminary results are encouraging because REM was the only tested antiviral drug that was somewhat effective for Covid-19 in clinical trials. It is not, however, a pharmacological "silver bullet” against Covid-19.

\section{Conclusions}

In conclusion, the widespread off label and irrational use of drugs for Covid-19 is cause for deep concern and might be contributing to the overall morbidity and mortality that has been attributed primarily to the infection. Of particular concern are the use of marcrolide antibiotics for a viral infection, and the use of antimalarial drugs CQ and HCQ for prophylaxis and treatment of mild Covid-19. There is already enough evidence from observational and clinical studies to show that risks of serious adverse events clearly outweigh hypothetical (still undemonstrated) clinical benefits when these antimalarials are used for preventive interventions and treatment of mild to moderate Covid-19. Therefore, prescription of CQ/HCQ for non-infected people or patients with asymptomatic or mild disease, be it off label or in clinical trials, is deemed unethical until proof to the contrary. Finally, the putative clinical benefits of remdesivir (REM) for Covid-19, or drug-induced reduction of time to clinical improvement by $31 \%$, are encouraging, but still need to be confirmed by additional clinical trials.

\section{Collaborations}

FJR Paumgartten and ACAX Oliveira jointly conceived the main ideas discussed in the article and are equally responsible for its conclusions. FJR Paumgartten elaborated a first version of the manuscript that was critically reviewed by ACAX Oliveira. Both authors approved the final version to be published. 


\section{References}

1. World Health Organization (WHO). Promoting rational use of medicines: core components. WHO Policy Perspectives on Medicines. Geneva: WHO; 2002.

2. May F. Whither 'rational' use of drugs? J Pharm Pract Res 2008; 38(2):89-91.

3. Sackett DL, Rosenberg WM, Gray JA, Haynes RB, Richardson WS. Evidence based medicine: what it is and what it isn't. BMJ 1996; 312(7023):71-72.

4. Paumgartten FJ, Delgado IF, Pitta LR, De-Oliveira ACAX. Drug repurposing clinical trials in the search for life-saving Covid-19 therapies; research targets and methodological and ethical issues. Vigil. Sanit. Debate 2020; 8(2):39-53.

5. Park SE. Epidemiology, virology, and clinical features of severe acute respiratory syndrome -coronavirus-2 (SARS-CoV-2; Coronavirus Disease-19). Clin Exp Pediatr. 2020; 63(4):119-124.

6. Poutanen SM, Low DE, Henry B, Finkelstein S, Rose D, Green K, Tellier R, Draker R, Adachi D, Ayers M, Chan AK, Skowronski DM, Salit I, Simor AE, Slutsky AS, Doyle PW, Krajden M, Petric M, Brunham RC, McGeer AJ; National Microbiology Laboratory, Canada; Canadian Severe Acute Respiratory Syndrome Study Team. Identification of severe acute respiratory syndrome in Canada. N Engl J Med 2003; 348(20):1995-2005.

7. Tsang K, Seto WH. Severe acute respiratory syndrome: scientific and anecdotal evidence for drug treatment. Curr Opin Investig Drugs 2004; 5(2):179185.

8. Tan EL, Ooi EE, Lin CY, Tan HC, Ling AE, Lim B, Stanton LW. Inhibition of SARS coronavirus infection in vitro with clinically approved antiviral drugs. Emerg Infect Dis 2004; 10(4):581-586.

9. D'Alessandro S, Scaccabarozzi D, Signorini L, Perego F, Ilboudo DP, Ferrante P, Delbue S. The Use of Antimalarial Drugs against Viral Infection. Microorganisms 2020; 8(1):85.

10. Savarino A, Boelaert JR, Cassone A, Majori G, Cauda R. Effects of chloroquine on viral infections: an old drug against today's diseases? Lancet Infect Dis 2003; 3(11):722-727.

11. Paumgarten FJR, Delgado IF, Pittta LR, De-Oliveira ACAX. Chloroquine and hydroxychloroquine repositioning in times of COVID-19 pandemic, All that glitters is not gold. Cad Saude Publica 2020; 36(5):e00088520.

12. Tai DY. Pharmacologic treatment of SARS: current knowledge and recommendations. Ann Acad Med Singapore 2007; 36(6):438-443.

13. Caly L, Druce JD, Catton MG, Jans DA, Wagstaff KM. The FDA-approved drug ivermectin inhibits the replication of SARS-CoV-2 in vitro. Antiviral Res 2020; 178:104787.

14. Xu J, Shi PY, Li H, Zhou J. Broad Spectrum Antiviral Agent Niclosamide and Its Therapeutic Potential. ACS Infect Dis 2020; 6(5):909-915.

15. Rossignol JF. Nitazoxanide: a first-in-class broad-spectrum antiviral agent. Antiviral Res 2014; 110:94-103.
16. Amici C, Di Caro A, Ciucci A, Chiappa L, Castilletti C, Martella V, Decaro N, Buonavoglia C, Capobianchi MR, Santoro MG. Indomethacin has a potent antiviral activity against SARS coronavirus. Antivir Ther 2006; 11(8):1021-1030.

17. World Health Organization (WHO). Report of the WHO-China Joint Mission on Coronavirus Disease 2019 (COVID-19). [cited 2020 May 11]. Available at: https://www.who.int/docs/default-source/coronaviruse/who-china-joint-mission-on-covid-19-final-report.pdf

18. Touret F, de Lamballerie X. Of chloroquine and COVID-19. Antiviral Res 2020; 177:104762.

19. Gautret P, Lagier JC, Parola P, Hoang VT, Meddeb L, Mailhe M, Doudier B, Courjon J, Giordanengo V, Vieira VE, Dupont HT, Honoré $S$, Colson P, Chabrière E, La Scola B, Rolain JM, Brouqui P, Raoult D. Hydroxychloroquine and azithromycin as a treatment of COVID-19: results of an open-label non-randomized clinical trial [published online ahead of print, 2020 Mar 20]. Int J Antimicrob Agents 2020; 105949.

20. Chen J, Liu D, Liu L, Liu P, Xu Q, Xia L, Ling Y, Huang D, Song S, Zhang D, Qian Z, Li T, Shen Y, Lu H. A pilot study of hydroxychloroquine in treatment of patients with common coronavirus disease-19 (Covid-19). J Zhejiang Univ (Med Sci) 2020; 49(1):215-219.

21. Mercuro NJ, Yen CF, Shim DJ, Maher TR, McCoy CM, Zimetbaum PJ, Gold HS. Risk of QT Interval Prolongation Associated With Use of Hydroxychloroquine With or Without Concomitant Azithromycin Among Hospitalized Patients Testing Positive for Coronavirus Disease 2019 (COVID-19). JAMA Cardiol 2020; e201834.

22. US Food and Drug Administration (FDA). Hydroxychloroquine or chloroquine for Covid-19: drug safety communication: FDA cautions against use outside of the hospital setting or a clinical trial due to risk of heart rhythm problems. Washington: US Food and Drug Administration; 2020 [cited 2020 May 1]. Available at: https://www.fda.gov/safety/medical

23. Nguyen LS, Dolladille C, Drici MD, Fenioux C, Alexandre J, Mira JP, Moslehi JJ, Roden DM, Funck-Brentano C, Salem JE. Cardiovascular Toxicities Associated with Hydroxychloroquine and Azithromycin: An Analysis of the World Health Organization Pharmacovigilance Database [published online ahead of print, 2020 May 22]. Circulation 2020; [acessado 2020 Maio 06]. Disponível em: https://doi.org/10.1161/ CIRCULATIONAHA.120.048238

24. Rosenberg ES, Dufort EM, Udo T, Wilberschied LA, Kumar J, Tesoriero J, Weinberg P, Kirkwood J, Muse A, DeHovitz J, Blog DS, Hutton B, Holtgrave DR, Zucker HA. Association of Treatment With Hydroxychloroquine or Azithromycin With In-Hospital Mortality in Patients With COVID-19 in New York State. JAMA 2020; 323(24):2493-2502. 
25. Gbinigie K, Frie K. What is the evidence for using macrolide antibiotics to treat COVID-19? Centre for Evidence-Based Medicine of the Nuffield Department of Primary Care Health Sciences of the University of Oxford. April 28 ${ }^{\text {th }}$, 2020. [cited 2020 May 11]. Available at: https://www.cebm.net/covid-19/what-is-theevidence-for-use-of-macrolide-antobiotics-for-treatmetnof-covid-19/

26. The National Institute for Health and Care Excellence (NICE). Covid-19 rapid guideline: managing suspected or confirrmed pneumonia in adults in the community. NICE Guideline. Apr 26, 2020. [cited 2020 Apr 30]. Available at: www.nice.org.uk/guidance/NG165

27. US Food and Drug Administration Coronavirus (COVID-19). Update: FDA Issues Emergency Use Authorization for Potential COVID-19 Treatment. Washington: US Food and Drug Administration; 2020. [cited 2020 May 1]. Available at: https://www.fda. gov/news-events/press-announcements/coronavirus-covid-19-update-fda-issues-emergency-use-authorization-potential-covid-19-treatment

28. Al Idrus A. Gilead's remdesivir speeds COVID-19 recovery in first controlled trial readout, but it's no 'silver bullet'. Fierce Covid-10 Update. FierceBiotech. [cited 2020 Apr 29]. Available at: https://www.fiercebiotech. com/biotech/silver-bullet

29. Ferner RE, Aronson JK. Remdesivir in covid-19. BMJ 2020; 369:m1610.

30. Sheahan TP, Sims AC, Graham RL, Menachery VD, Gralinski LE, Case JB, Leist SR, Pyrc K, Feng JY, Trantcheva I, Bannister R, Park Y, Babusis D, Clarke MO, Mackman RL, Spahn JE, Palmiotti CA, Siegel D, Ray AS, Cihlar T, Jordan R, Denison MR, Baric RS. Broad-spectrum antiviral GS-5734 inhibits both epidemic and zoonotic coronaviruses. Sci Transl Med 2017; 9(396):1-20.

31. Wang M, Cao R, Zhang L, Yang X, Liu J, Xu M, Shi Z Hu Z, Zhong W, Xiao G. Remdesivir and chloroquine effectively inhibit the recently emerged novel coronavirus (2019-nCoV) in vitro. Cell Res 2020; 30(3):269271.

32. Grein J, Ohmagari N, Shin D, Diaz G, Asperges E, Castagna A, Feldt T, Green G, Green ML, Lescure FX, Nicastri E, Oda R, Yo K, Quiros-Roldan E, Studemeister A, Redinski J, Ahmed S, Bernett J, Chelliah D, Chen D, Chihara S, Cohen SH, Cunningham J, D’Arminio Monforte A, Ismail S, Kato H, Lapadula G, L'Her E, Maeno T, Majumder S, Massari M, Mora-Rillo M, Mutoh Y, Nguyen D, Verweij E, Zoufaly A, Osinusi AO, DeZure A, Zhao Y, Zhong L, Chokkalingam A, Elboudwarej E, Telep L, Timbs L, Henne I, Sellers S, Cao H, Tan SK, Winterbourne L, Desai P, Mera R, Gaggar A, Myers RP, Brainard DM, Childs R, Flanigan T. Compassionate use of remdesivir for patients with severe Covid-19. N Engl J Med 2020; 382(24):23272336.
33. Wang $Y$, Zhang D, Du G, Du R, Zhao J, Jin Y, Fu S, Gao L, Cheng Z, Lu Q, Hu Y, Luo G, Wang K, Lu Y, Li H, Wang S, Ruan S, Yang C, Mei C, Wang Y, Ding D, Wu F, Tang X, Ye X, Ye Y, Liu B, Yang J, Yin W, Wang A, Fan G, Zhou F, Liu Z, Gu X, Xu J, Shang L, Zhang Y, Cao L, Guo T, Wan Y, Qin H, Jiang Y, Jaki T, Hayden FG, Horby PW, Cao B, Wang C. Remdesivir in adults with severe COVID-19: a randomised, double-blind, placebo-controlled, multicentre trial. Lancet 2020; 395(10236):1569-1578.

34. Beigel JH, Tomashek KM, Dodd LE, Mehta AK, Zingman BS, Kalil AC, Hohmann E, Chu HY, Luetkemeyer A, Kline S, Castilla DL, Finberg RW, Dierberg K, Tapson V, Hsieh L, Patterson TF, Paredes R, Sweeney DA, Short WR, Touloumi G, Lye DC, Ohmagari N, Oh MD, Ruiz-Palacios GM, Benfield T, Fätkenheuer G, Kortepeter MG, Atmar RL, Creech CB, Lundgren J, Babiker AG, Pett S, Neaton JD, Burgess TH, Bonnett T, Green M, Makowski M, Osinusi A, Nayak S, Lane HC, ACTT-1 Study Group Members. Remdesivir for the Treatment of Covid-19 - Preliminary Report [published online ahead of print, 2020 May 22]. N Engl J Med 2020; 10.1056/NEJMoa2007764.

Article submitted 26/05/2020

Approved 27/05/2020

Final version submitted 29/05/2020 
